\title{
Diversity of Endomycorrhizal Fungi in the Rhizosphere of Chickpea in Morocco
}

\author{
N. EL HAZZAT, M. ARTIB, J. TOUATI, M. CHLIYEH, K. SELMAOUI, \\ A. OUAZZANI TOUHAMI, R. BENKIRANE and A. DOUIRA* \\ Laboratory of Botany Biotechnology and Plant Protection, Department of Biology, \\ Faculty of Sciences BP. 133, Ibn Tofail University, Kenitra, Morocco
}

(Received: 26 March 2018; accepted: 29 May 2018)

\begin{abstract}
The endomycorrhizal fungi diversity in the rhizosphere of chickpea (Cicer arietinum L.) and the evaluation of root mycorrhizal level were studied in six regions of Morocco: Tahla, Sefrou, Souk Larbae, Souk Tlat, Ouazzane and Jarf Melha. All chickpea roots are carrying endomycorrhizal structures. Root mycorrhizal parameters varied from one site to another, and the highest frequency and intensity of mycorrhization was recorded in the roots of chickpea plants at the two sites Tahla and Jarf Melha respectively, 83\%, 33\% and $25.03 \%$. In addition, the highest arbuscular content was also noted in the roots of plants growing in the site of Tahla (22.18\%) while the lowest content was noted at the site of Sefrou (2.07\%). However, the vesicles were not observed in all the sites.

The highest numbers of endomycorrhizal spores were recorded in the rhizosphere of plants collected in Jarf Melha and Tahla, respectively, 74 and 41 spores / $100 \mathrm{~g}$ soil. All spores found in the studied sites are represented by 22 morphotypes belonging to 7 genera: Glomus (13 species), Acaulospora (4 species), Gigaspora (one species), Radekera (one species), Entrophospora (one species), Pacispora (one species), Dentiscutata (one species).
\end{abstract}

Keywords: Endomycorrhizal fungi, legumes, chickpea, Morocco.

Legumes play several nutritional, agronomic and economic roles (El Baghati, 1995). They are a major source of protein and vegetable oils (Graham and Vance, 2003), provide $22 \%$ protein, $32 \%$ fat and $7 \%$ carbohydrate for human nutrition (Wery and Grignac, 1983) and on agronomic level, legumes provide better nitrogen fertilization (Valantin-Morison et al., 2012; Amossé et al., 2013).

The best-known biological characteristic of legumes is their ability to associate with soil bacteria (rhizobia), to form root symbiotic organs in which these bacteria transform atmospheric nitrogen into an easily assimilated form by the plant (Hardy and Hoolsten, 1985) and thus contribute to the improvement of soil structure and nitrogen enrichment (Azcon-Aguilar et al., 2003).

Legumes are also able, like most wild or cultivated plants, to associate with vesicular and arbuscular mycorrhizae to form endomycorrhizae (Gianinazzi-Pearson et al., 1996; Harrison, 1997). This association is beneficial and has a positive effect on plant

\footnotetext{
* Corresponding author; e-mail: douiraallal@gmail.com
} 
growth (Karagiannidis and Hadjisavva-Zinoviadi, 1998), and mineral nutrition, especially in phosphorus deficiency conditions (Lambers et al., 2008).

The dual symbiotic association observed in leguminous plants is also of economic and ecological interest, it will limit the use of chemical fertilizers (Thomsen and Haugaard-Nielsen, 2008), which will reduce production expenses and protect environment (Harrison, 1997; Mougel et al., 2006; Udvardi and Poole, 2013). These two types of symbiotic interactions mobilize the soil resources poorly accessible especially phosphorus and import nitrogen from the atmosphere (Harrison, 1997).

Information on the double symbiosis of legumes, such as chickpea, is still rare or non-existent in Morocco. Endomycorrhizal fungi linked for example to chickpea roots are not known in Morocco.

In order to fully exploit the beneficial effects of symbiotic associations, it will first be necessary to elucidate the diversity of species that can form symbiotic association with the roots of the legumes. The objective of this work is to study the diversity of endomycorrhizal fungi related to the rhizosphere of chickpea plants growing in different regions of Morocco.

\section{Materials and Methods}

\section{Sampling}

Soil samples were taken from the rhizosphere of chickpea plants (local population), from six regions of Morocco, Tahla, Sefrou, Ouazzane, Jarf Melha, Souk Tlat, and Souk Larbae (Table 1). For each site, five samples of $2 \mathrm{~kg}$ of soil were randomly taken from the surface horizon $(0-20 \mathrm{~cm})$ and a composite soil sample was taken per site.

Table 1

Sampling sites and chemical characteristics of collected soils

\begin{tabular}{|c|c|c|c|c|c|c|c|c|}
\hline \multirow[t]{2}{*}{ Région } & \multirow[t]{2}{*}{ Variety } & \multirow{2}{*}{$\begin{array}{l}\text { Planting } \\
\text { date }\end{array}$} & \multirow[t]{2}{*}{ prospection } & \multicolumn{5}{|c|}{ Soil properties } \\
\hline & & & & $\mathrm{pH}$ & $\begin{array}{l}\text { Mineral } \\
\text { nitrogen } \\
(\mathrm{ppm})\end{array}$ & $\begin{array}{l}\text { Assimilable } \\
\text { phosphorus } \\
(\mathrm{ppm})\end{array}$ & $\begin{array}{l}\text { Assimilable } \\
\text { potassium } \\
(\mathrm{ppm})\end{array}$ & $\begin{array}{l}\text { Organic } \\
\text { matter \% }\end{array}$ \\
\hline Tahla & Local & February & $\begin{array}{l}\text { Between } 20 \\
\text { and } 29 \text { May }\end{array}$ & 7.90 & 90.60 & 30.6 & 739.5 & 3.50 \\
\hline Sefrou & Local & March & $\begin{array}{l}\text { Between } 20 \\
\text { and } 29 \text { May }\end{array}$ & 8.0 & 110.60 & 20 & 910 & 8.10 \\
\hline Ouazzane & Local & February & $\begin{array}{l}\text { Between } 20 \\
\text { and } 29 \text { May }\end{array}$ & 8.01 & 80.20 & 8 & 350 & 4.6 \\
\hline Jarf Melha & Local & February & $\begin{array}{l}\text { Between } 20 \\
\text { and } 29 \text { May }\end{array}$ & 7.95 & 86.60 & 7 & 124 & 3.5 \\
\hline Souk Tlat & Local & February & $\begin{array}{l}\text { Between } 20 \\
\text { and } 29 \text { May }\end{array}$ & 8.30 & 80.80 & 16.8 & 260.8 & 1.80 \\
\hline Souk Larbae & Local & February & $\begin{array}{l}\text { Between } 20 \\
\text { and } 29 \text { May }\end{array}$ & 7.85 & 84.60 & 14.2 & 296 & 1.61 \\
\hline
\end{tabular}




\section{Extraction of spores}

The spores were extracted according to the wet sieving method described by Gerdemann and Nicolson (1963). In a $1 \mathrm{~L}$ beaker, $100 \mathrm{~g}$ of each composite soil sample was immersed in $0.5 \mathrm{~L}$ of running water and stirred for $1 \mathrm{~min}$ with a spatula. After 10 to 30 seconds of decantation, the supernatant was passed through a sieve of four bunks with decreasing mesh size $(500,200,80$ and $50 \mu \mathrm{m})$. This operation was repeated twice. The contents retained by the sieves of 200, 80 and $50 \mu \mathrm{m}$ were distributed in two tubes and centrifuged for $4 \mathrm{~min}$ at $9000 \mathrm{rpm}$. The supernatant was removed and a viscosity gradient was thereby created by adding $20 \mathrm{~mL}$ of a $40 \%$ sucrose solution in each centrifuge tube (Walker, 1992). The mixture was rapidly stirred and the tube was again centrifuged for 1 minute at $9000 \mathrm{rpm}$. In contrast to the first centrifugation step, the supernatant was poured onto the sieve with a mesh of 50 microns, the resulting substrate was rinsed with distilled water to remove sucrose and then disinfected with an antibiotic solution.

The spores were observed under an optical microscope and identified morphologically according to several criteria including spore color, shape, size, surface ornamentation. Spore identification was performed according to the descriptions provided by the International Collection of Arbruscular Vesicular Mycorrhizal Fungi (INVAM, 2014).

\section{Evaluation of mycorhization parameters}

MA fungi do not cause obvious morphological changes to the roots. However, they produce arbuscules and in many cases, vesicles. Observation of MA structures within the roots requires clearing the cortical cells of the cytoplasm and the phenolic compounds that usually hide them, and then staining the fungal tissue differently (Utobo et al., 2011).

The observation of the roots was prepared according to the method of Philips and Hayman (1970). This technique involves extracting and cutting the finest roots over a length of $1 \mathrm{~cm}$, wash them with water, and immerse them in a $10 \% \mathrm{KOH}$ solution: (potassium hydroxide) and then place them in the water bath at $90{ }^{\circ} \mathrm{C}$ for one hour to remove the cytoplasmic contents. Then the roots are rinsed and transferred to $\mathrm{H}_{2} \mathrm{O}_{2}$ solution for 20 minutes at $90{ }^{\circ} \mathrm{C}$ in the water bath until the roots become whitish. After rinsing, the roots are stained with cresyl blue in $100 \mathrm{ml}$ of distilled water and returned to the water bath at $90{ }^{\circ} \mathrm{C}$ for 15 minutes.

The arbuscular frequencies and the content of endomycorrhizal fungi within the roots were measured by assigning a mycorrhizal index ranging from 0 to 5 (Derkowska et al., 2008). Thirty randomly selected fragments were used for microscopic observation and calculation of mycorrhizal parameters, namely mycorrhizal frequency (MF\%), mycorrhizal intensity (MI\%), and arbuscular and vesicular contents. according to the Mycorhizal index of Trouvelot et al. (1986).

\section{Statistical analysis}

The statistical treatment of the results was based on the analysis of variance with a single classification criterion (ANOVA). 


\section{Results}

The chickpea roots growing in the different sites studied are mycorrhizal. Different structures of endomycorrhizae have been observed: hyphae and arbuscules (Fig. 1). The mycorrhizal frequency of chickpea roots varies from one site to another (Table 2). The highest frequencies were recorded in the roots of chickpea plants growing in the sites of Tahla and Jarf Melha, 83.33\%, the frequency of mycorrhizal roots in the sites of Souk Tlat, Souk Larbae and Ouazzane is $76.66 \%$, and that of Sefrou is about $63.33 \%$.

The highest mycorrhizal intensity was observed at the site of Jarf Melha (25.03\%), and the lowest at Sefrou (6.43\%).

The highest arbuscular content was recorded in the roots of chickpea plants at the Tahla site $(22.18 \%)$, followed by Jarf Melha (16.34\%), Souk Tlat $(6.71 \%)$ and Souk Larbae $(6.36 \%)$. The values recorded in Ouazzane and Sefrou sites are the lowest, respectively, $3.16 \%$ and $2.07 \%$. In contrast, vesicles were not observed in the chickpea roots collected from the sites of Tahla and Jarf Melha.

The number of spores found in the rhizosphere of chickpea plants growing in the sites studied varies between 74 and 41 spores / $100 \mathrm{~g}$ of soil, respectively, at the Jarf Melha and Tahla sites (Table 3). Twenty-two morphotypes (Fig. 2) were identified, represented by Glomus versiforme, G. fecundisporum, G. clarum, G. margarita, G. microcarpum, G. badium, G. intraradices, G. deserticola, G. macrocarpum, G. etunicatum, G. aggrega-

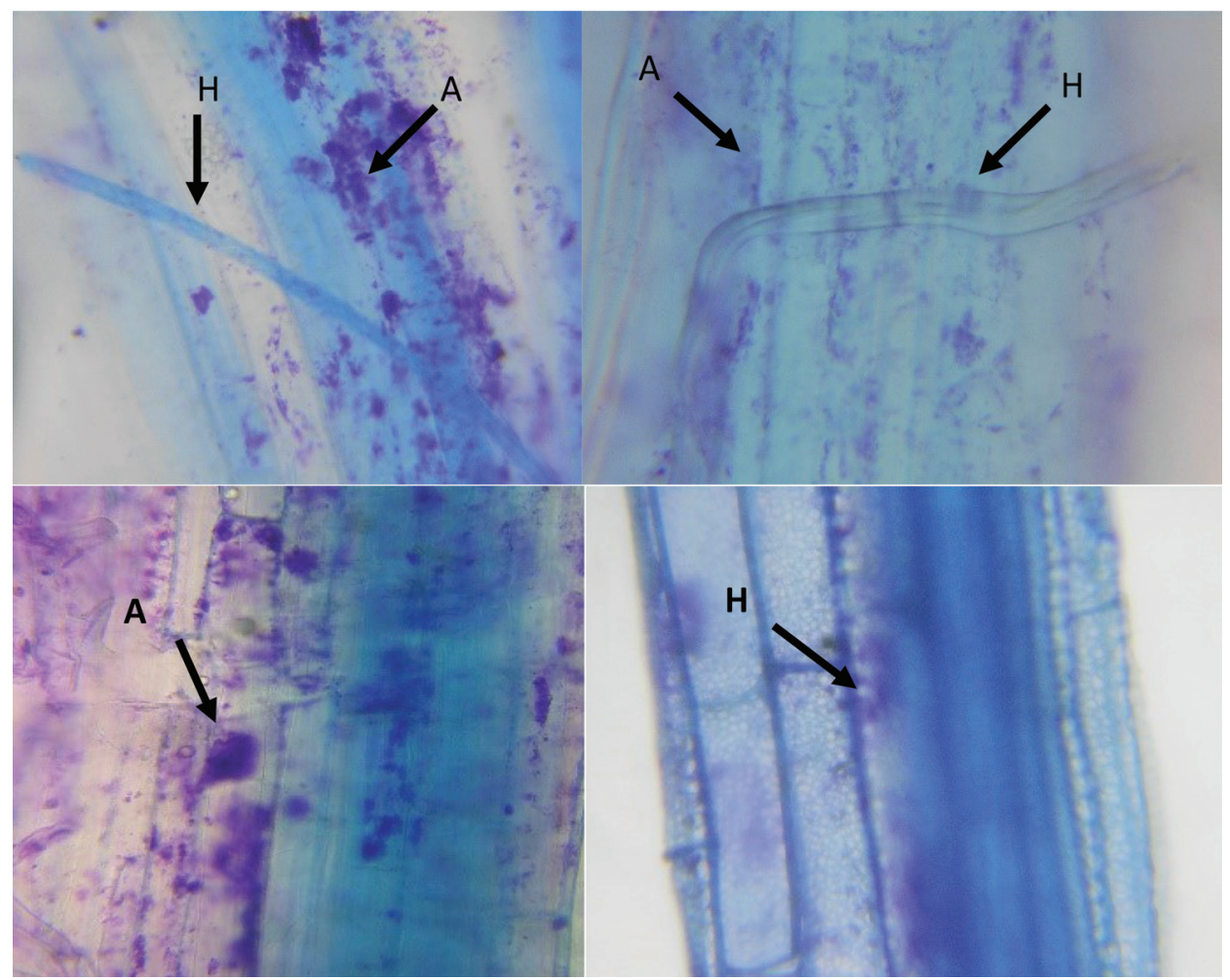

Fig. 1. Endomycorrhizal structures in fine chickpea roots: Arbuscules (A), Hyphal (H) 
tum, Glomus sp., Acaulosporanigra, A. laevis, A. gedanessis, Acaulospora sp., Gigaspora margarita, Gigaspora sp., Radekera fulva, Entrophospora inferquen, Pacispora scintilus, Dentisculata biornata (Table 3). These species have been grouped into 7 genera (Glomus, Acaulospora, Gigaspora, Radekera, Entrophospora, Pacispora, Dentiscutata), 5 families (Glomeraceae, Gigasporaceae, Acaulosporacea, Pacisporacea and Entrophosporacea) and 3 orders (Glomerales, Gigasporales, Diversisporales.

Representatives of the genus Glomus are encountered in all sites studied (Fig. 4). Glomus versiforme is the most abundant species at Jarf Melha, Tahla, Ouazzane and Souk Tlat sites, with respectively, 18, 13, 12 and 5 spores / $100 \mathrm{~g}$ of soil. Acaulospora sp. is the

Table 2

Mycorrhizal parameters in chickpea roots growing in the studied sites

\begin{tabular}{lccrrrc}
\hline Mycorrhizal parameters (\%) & Tahla & Souk Larbae & Souk Tlat & Sefrou & Ouazzane & Jarf Malha \\
\hline Mycorrhizal frequency & $83.33^{\mathrm{a}}$ & $76.66^{\mathrm{a}}$ & $76.66^{\mathrm{a}}$ & $63.33^{\mathrm{a}}$ & $76.66^{\mathrm{a}}$ & $83.33^{\mathrm{a}}$ \\
Arbuscular content & $22.18^{\mathrm{a}}$ & $6.36^{\mathrm{c}}$ & $6.71^{\mathrm{c}}$ & $2.07^{\mathrm{d}}$ & $3.16^{\mathrm{d}}$ & $16.34^{\mathrm{b}}$ \\
Mycorrhizal intensity & $24^{\mathrm{a}}$ & $7.53^{\mathrm{c}}$ & $15.73^{\mathrm{b}}$ & $6.43^{\mathrm{c}}$ & $16.4^{\mathrm{b}}$ & $25.03^{\mathrm{a}}$ \\
\hline
\end{tabular}

Two values read on the same line, followed by the same letter, are not significantly different at the $5 \%$ threshold according to the Newman and Keuls test

Table 3

Identification of endomycorrhizal fungi in the different sites studied

\begin{tabular}{|c|c|c|c|c|c|c|c|}
\hline $\begin{array}{l}\text { Num- } \\
\text { ber }\end{array}$ & Species & Form & Color & $\begin{array}{l}\text { Spore's } \\
\text { size }\end{array}$ & Wall size & $\begin{array}{l}\text { Spore's } \\
\text { surface }\end{array}$ & $\begin{array}{l}\text { Hyphae } \\
\text { length }\end{array}$ \\
\hline 1 & G. versiforme & Brown yellow & Globular & 70 & 2.5 & Granular & - \\
\hline 2 & G. intraradices & Yellow & Globular & 77.5 & 2.5 & Granular & \\
\hline 3 & G. aggregatum & Orange & Globular & 70 & 2.5 & Smooth & \\
\hline 4 & P. scintillans & Dark brown yellow & Globular & 65 & 2.5 & Granular & \\
\hline 5 & Entrophospora sp. & Brown & Globular & 70 & 2.5 & Granular & \\
\hline 6 & A. nigra & Globular & Black & 100 & 2.5 & Smooth & \\
\hline 7 & Gigaspora sp. & Yellow & Globular & 70 & 2.5 & Smooth & \\
\hline 8 & D. biornata & Dark brown & Globular & 75 & 2.5 & & \\
\hline 9 & G. clarum & Light yellow brown & Globular & 75 & 2.5 & Granular & \\
\hline 10 & G. badium & Brown & Globular & 70 & 2.5 & Smooth & \\
\hline 11 & Acaulospora sp. & Yellow & Globular & 125 & 2.5 & Smooth & \\
\hline 12 & A. laevis & Light yellow & Globular & 77.5 & 2.5 & Granular & \\
\hline 13 & G. fecundisporum & Orange & Globular & 72.5 & 2.5 & Granular & \\
\hline 14 & G. margarita & Yellow brown & Globular & 70 & 2.5 & Granular & \\
\hline 15 & R. fulva & Light brown & Globular & 75 & 2.5 & Granular & \\
\hline 16 & A. gedanessis & Light yellow & Globular & 70 & 2.5 & Granular & \\
\hline 17 & E. inferquens & Brown yellow & Globular & 75 & 2.5 & Granular & \\
\hline 18 & G. macrocarpum & Light brown & Globular & 62.5 & 2.5 & Smooth & \\
\hline 19 & G. deserticola & Dark brown & Globular & 75 & 2.5 & Smooth & \\
\hline 20 & G. etunicatum & Yellow brown & Globular & 37.5 & 2.5 & Granular & \\
\hline 21 & Glomus sp. & Yellow & Globular & 75 & 2.5 & Smooth & \\
\hline 22 & G. microcarpum & Globular & Yellow brown & 75 & 2.5 & Granular & \\
\hline
\end{tabular}

G: Glomus, A: Acaulospora, E: Entrophospora, Gi: Gigaspora, D: Dentiscutata, R: Radekera, P: Pacispora 


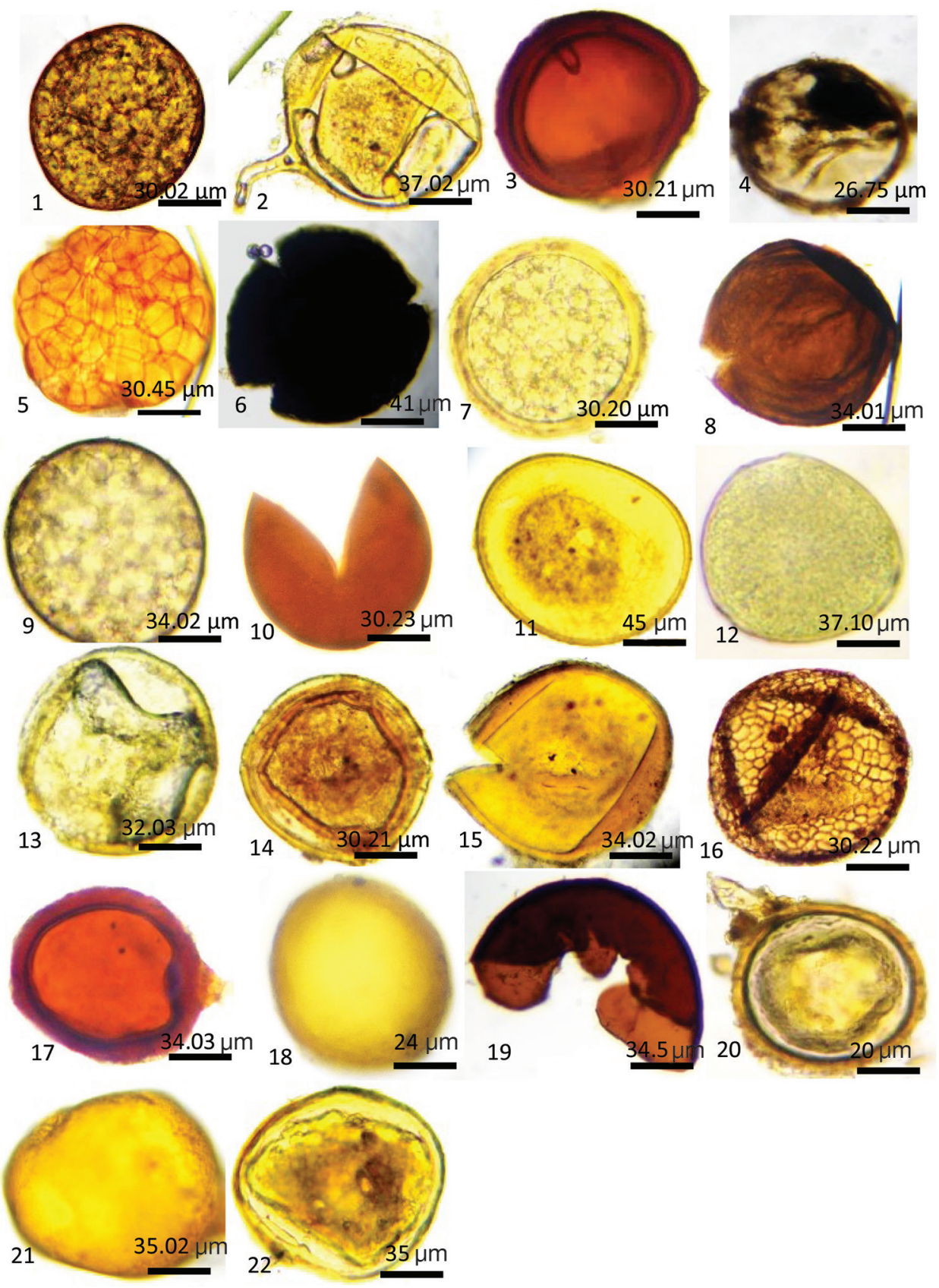

Fig. 2. Species of endomycorrhizal fungi isolated from the chickpea rhizosphere of the different sites studied 


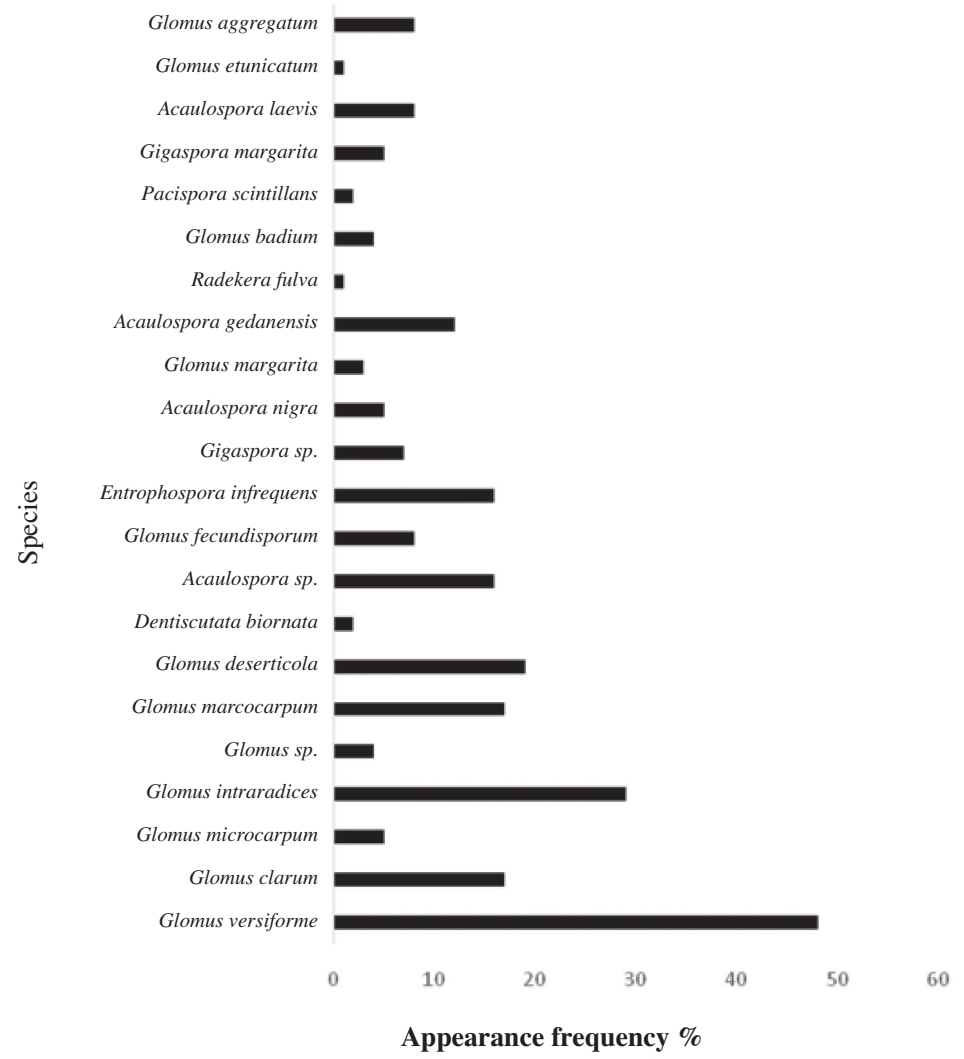

Fig. 3. Occurrence frequency of endomycorrhizal fungi species in the different sites studied

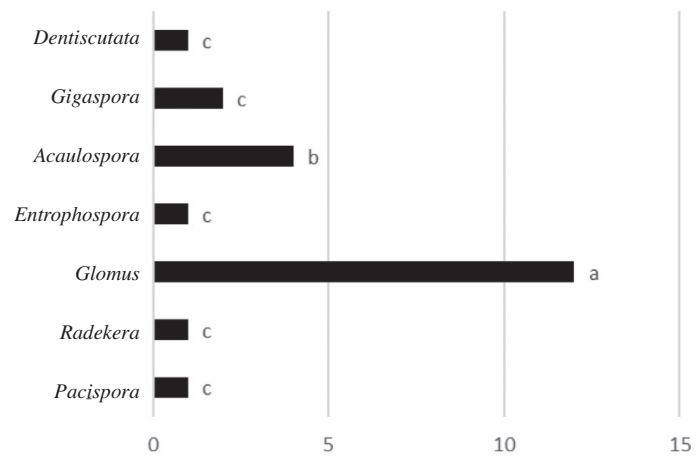

Appearance frequency $\%$

Fig. 4. Appearance frequency of genera in the different sites studied 
most dominant species in the rhizosphere of chickpea plants growing at the site of Souk Larbae, with 9 spores / $100 \mathrm{~g}$ of soil, and Glomus clarum is the most represented at the site Sefrou, with 7 spores / $100 \mathrm{~g}$ of soil (Table 4).

\section{Table 4}

Occurrence frequency of species at the different sites studied

\begin{tabular}{|c|c|c|c|c|c|c|}
\hline \multirow[t]{2}{*}{ Species } & \multicolumn{6}{|c|}{ Spore's number $/ 100 \mathrm{~g}$ of soil } \\
\hline & Tahla & Souk Larbae & Souk Tlat & Sefrou & Ouazzane & Jarf Melha \\
\hline G. versiforme & - & - & 5 & - & 12 & 18 \\
\hline G. clarum & 2 & - & 2 & 7 & 1 & 5 \\
\hline G. microcarpum & 5 & - & - & - & - & - \\
\hline G. intraradices & 4 & 2 & 4 & 6 & 3 & 10 \\
\hline Glomus sp. & - & - & 3 & - & 1 & - \\
\hline G. macrocarpum & 6 & 2 & - & 5 & 4 & 4 \\
\hline G. deserticola & 2 & 3 & - & 4 & 4 & 6 \\
\hline D. biornata & - & 2 & - & - & - & - \\
\hline Acaulospora sp. & 3 & 9 & 3 & 1 & - & - \\
\hline G. fecundisporum & - & 5 & - & 3 & - & - \\
\hline E. inferquens & 1 & 2 & - & - & 1 & 12 \\
\hline Gigaspora sp. & & 2 & 2 & 1 & 2 & - \\
\hline A. nigra & 5 & - & - & - & - & 2 \\
\hline A. gedanessis & - & 5 & 2 & - & - & 5 \\
\hline R. fulva & - & 1 & - & - & - & - \\
\hline G. badium & - & - & 2 & - & 2 & - \\
\hline P. scintillans & - & - & - & 2 & - & - \\
\hline Gi. Margarita & - & 3 & - & - & - & 2 \\
\hline G. margarita & - & - & 3 & - & - & - \\
\hline G. aggregatum & - & - & 3 & - & - & 5 \\
\hline A. laevis & - & - & - & - & 2 & 6 \\
\hline G. etunicatum & - & - & - & 1 & - & - \\
\hline Total number of spores & 41 & 36 & 31 & 34 & 32 & 74 \\
\hline
\end{tabular}

G: Glomus, A: Acaulospora, E: Entrophospora, Gi: Gigaspora, D: Dentiscutata, R: Radekera, P: Pacispora

Glomus versiforme is present in all the sites (48\%), followed by Glomus intraradices (29\%), Glomus deserticola (19\%), Glomus macrocarpum, Glomus clarum (17\%) and Entrophospora inferquens (16\%) (Fig. 3).

The size of the spores varies from one genus to another, Glomus varies from $[77.5 \mu \mathrm{m}-37 \mu \mathrm{m}]$, Acaulospora $[125 \mu \mathrm{m}-70 \mu \mathrm{m}]$ and the genus Gigaspora $70 \mu \mathrm{m}$. From the identification results, it appears that the genus Glomus is the genus with the smallest size.

\section{Discussion}

The chickpea roots developing in the different sites studied (Tahla, Sefrou, Souk Tlat, Souk Larbae and Ouazzane) are mycorrhizal. The chickpea roots developing in the different sites studied (Tahla, Sefrou, Souk Tlat, Souk Larbae and Ouazzane) are mycor- 
rhizal. The determination of the parameters characterizing the endomycorrhizae allowed to note only the presence of the arbuscules, units at which exchanges occur between the host and the fungus.

Spore density in the rhizosphere of chickpea plants varies from site to another. It is represented by 22 species of mycorrhizal fungi belonging to 7 genera Glomus (13 species), Acaulospora (4 species), Gigaspora (one species), Radekera (one species), Entrophospora (one species), Pacispora (one species), Dentiscutata (one species). Representatives of the genus Glomus are the most abundant (13 species).

The soils of the sites studied are almost basic, low in assimilable phosphorus and rich in nitrogen. Physicochemical parameters are considered essential in the distribution and abundance of mycorrhizal fungi (Boudarga et al., 2015). Mosse (1973) noted that the genus Glomus often appears in neutral or alkaline $\mathrm{pH}$ soils. According to Brundrett, (1991), the species that are growing out of culture season can influence the composition of associated fungi, and the more the number of plant species increases, the more the number of endomycorrhizal fungi increases.

This dominance has also been reported in Morocco in the rhizosphere of the olive tree (Kachkouch et al., 2012, 2014; Chliyeh et al., 2014), oleaster (Sghir et al., 2013), date palm (Sghir et al., 2015), Ceratonia siliqua (El Asri et al., 2014; Talbi et al., 2015), Populus alba and juncus (Talbi et al., 2014) and sugarcane (Selmaoui et al., 2017). According to Bever et al. (1996), the dominance of the genus Glomus is due to its ability to produce more spores in a shorter time than other genera such as Gigaspora and Scutellospora. This abundance is also due to its adaptation to drought and soil salinity (Haas and Menge, 1990; Blaszkowski et al., 2002).

Glomus intraradices is common and has been isolated from all studied sites. Other species have been found only at some sites, D. biornata and R. fulva in Souk Larbae, G. microcarpum in Tahla, G. margarita in Souk Tlat and P. scintilans and G. etunicatum in Sefrou. Sometimes a species is found in two sites, S. nigra in Tahla and Jarf Melha, G. fecundisporum in Souk Larbae and Sefrou, A. laevis in Ouazzane and Jarf Melha, G. margarita in Souk Larbae and Jarf Melha and G. badium in Souk Tlat and Jarf Melha.

The AM fungi species richness in the sites studied is almost identical and varies between 9 and 11 species. Attitchabi et al. (2008) noted that the species richness of AM fungi in natural forests is higher compared with the agricultural fields. Undisturbed forest lands (Shi et al., 2007; Attitchabi et al., 2008; Leal et al., 2009), herbal lands (Oehl et al., 2003) and desert plantations (Stutz et al., 2000) recorded a high species richness of AM fungi than agricultural lands (Oehl et al., 2003). Commonly, according to Fortin et al. (2008), agricultural fields are poor in AMF, this poverty is probably due to the cultural practices that modify diversity and reduce the amount of mycorrhizal propagules. The type of use and the intensity of exploitation have a great influence on the communities of AM fungi in agricultural soils (Oehl et al., 2011). According to these authors, for example, grasslands generally have higher diversity than crops, indeed, extensive exploitation leads to an increase in the number of species and intensive exploitation reduces it, therefore, more species of AM fungi are found in soils uncultivated or little worked than those that are frequently cultivated.

Similarly, it should be noted that soils traumatized by earthworks, loading and unloading works are less rich in endomycorrhizal propagules (El Hazzat et al., 2017). Other studies have also shown that disturbed soil can affect the distribution of arbuscular mycorrhizal fungi (Nicolson, 1960). 
Soils in semi-arid regions are generally poor in nutrients (Sanaa, 1993) and field crop yields are highly dependent on spatial and temporal variations in rainfall. Thus, the improvement of soil fertility is necessary (Lahlou et al., 2005). Mycorrhizal arbuscular fungi are one of the key groups to ensure productivity and cultural safety (Chibani, 2011) and constitute a microbial component of the soil that is important for sustainable land management practices (Mouelhi et al., 2016).

AMF are important fungal colonizers of plant roots in semi-arid areas characterized by a water deficit (Khidir et al., 2010) and are also known for their involvement in improving mineral nutrient uptake especially phosphorus (Lambers et al., 2008), the macro$(\mathrm{N}, \mathrm{K}, \mathrm{Mg}, \mathrm{Na}, \mathrm{S}$ ) and the micro-soil nutrients (B, Br, Cl, Cu, Cr, Cs, Co, Fe, Mo, Mn, $\mathrm{Ni}, \mathrm{Si}, \mathrm{Zn}$ ) (Smith and Read, 2008), water supply and plant resistance to water stress and diseases (Mandyam and Jumpponen, 2005; St-Arnaud and Vujanovic, 2007). They also have a positive effect on plant growth (Karagiannidis and Hadjisavva-Zinoviadi, 1998).

Legumes are generally sensitive to abiotic constraints such as salinity and aridity. These environmental constraints are widespread in Morocco and affect the productivity of legumes especially during dry years. Beans, chickpeas and peas are known to be the most sensitive legumes (Cordivilla et al., 1995; Soussi et al., 1998), while soybeans are more tolerant (Delgado et al., 1994).

The development of chickpea culture depends on the valorization of endomycorrhizal diversity through the use of biotechnological techniques. This endomycorrhizal diversity has been demonstrated in the rhizosphere of chickpea and the species found can be exploited to improve the growth of plants and for the protection of their roots against telluric pathogens, like Fusarium. Indeed, mycorrhizae are biostimulators and bioprotectors. The inoculation of chickpea by native AMF may improve plant growth, particularly in terms of rooting protect plants against telluric diseases. It is necessary to achieve this objective to select certain species or a complex of fungi, consisting of several species, having both a high infectivity and a good adaptation to the different climatic and edaphic conditions. In 2011, Farzaneh et al. have shown that mycorrhizal chickpea by commercial inoculum increase the collection of micro- and macronutrients from a root mycorrhization rate of 18 to $55 \%$.

The contribution of AMF as inoculum, biofertilizers and bio-stimulant, and its effect on the growth of legumes will help increase the availability of nutrients for plants in poor soil. The coating of legume seeds with endomycorrhizae may also ensure the mycorrhization of the seedlings as soon as they germinate and will allow a homogeneous distribution of the inoculum. The establishment of a fungus-root relationship will be easier if it is realized from the beginning. In such cases, this relationship will work in the right direction and will directly contribute to the proper development of plants and the protection of roots against soil-borne parasites.

\section{Conclusion}

The rhizosphere of chickpea plants growing in the different sites studied is rich in endomycorrhizal fungi species. These species can be isolated, propagated and exploited by different biotechnological processes to improve plant growth and to protect their roots against soil borne pathogens. 


\section{Literature}

Amossé, C., Jeuffroy, M. H. and David, C. (2013): Relay intercropping of legume cover crops in organic winter wheat. Effects on performance and resource availability. Field Crops Research 145, 78-87.

Attitchabi, J., Coyne, D., Hountondji, F., Lawouin, L., Wiemken, A. and Oehl, F. (2008): Arbuscular mycorrhizal fungi in the 'Yam Belt' of West Africa. African J. Biotechnol. 56, 256-268.

Azcon-Aguilar, C., Palenzuela, J., Roldan, A., Bautsta, S., Vallejo, R. and Barea, J. M. (2003): Analysis of the mycorrhizal potential in the rhizosphere of representative plant species from desertification-threatened Mediterranean shrublands. Appl. Soil Ecology 22, 29-37.

Bever, J. D., Morton, J. B., Antonovics, J. and Schultz, P. A. (1996): Host-dependent sporulation and species diversity of arbuscular mycorrhizal fungi in mown grassland. J. Ecol. 84, 71-82.

Blaszkowski, J., Adamska, I. and Madej, T. (2002): Glomus lamellosum (Glomales, Zygomycota), an arbuscular mycorrhizal fungal species new for Poland and Europe. Mycotaxon 81, 281-292.

Boudarga, K., Dalpé, Y., Beryouni, K., Saber, N. and Kandil, M. (2015): Impact of crop rotation on mycorrhizal fungi in irrigated soils of the Doukkala (Morocco). International J. Environmental and Agriculture Research 1, 48-55.

Brundrett, M. C. (1991): Mycorrhizas in natural ecosystems. In: A. Macfayden, M. Begon and A. H. Fitter (eds): Advances in Ecological Research, Vol. 21, Academic Press, London, pp. 171-313.

Chibani, R. (2011): Evaluation de la pratique du Semis Direct en Tunisie. Stabilité structurale et séquestration du carbone dans les Sols, $21 \mathrm{p}$.

Chliyeh, M., Ouazzani Touhami, A., Filali-Maltouf, A., El Modafar, C., Moukhli, A., Oukabli, A., Benkirane, R. and Douira, A. (2014): Effect of a composite endomycorrhizal inoculum on the growth of olive trees under nurseries conditions in Morocco. Int. J. Pure App. Biosci. 2 , 1-14.

Cordovilla, M. P., Ocana, A., Ligero, F. and Lluch, C. (1995): Salinity effects on growth analysis and nutrient composition in four grain legumes-Rhizobium symbiosis. J. Plant Nutr. 18, 1595-1609.

Delgado, M. J., Ligero, F. and Lluch, C. (1994): Effects of salt stress on growth and nitrogen fixation by pea, faba-bean, common bean and soybean plants. Soil Biol. Biochem. 26, 371-376.

Derkowska, E., Sas-Paszt, L., Sumorok, B., Szwonek, E. and Gluszek, S. (2008): The influence of mycorrhization and organic mulches on mycorrhizal frequency in apple and strawberry roots. J. Fruit and Ornamental Plant Research 16, 227-242.

El Asri, A., Talbi, Z., Ait Aguil, F., Chliyeh, M., Sghir, F., Touati, J., Ouazzani Touhami, A., Benkirane, R. and Douira, A. (2014): Arbuscular mycorrhizal fungi associated with Rhizosphere of carob tree (Ceratonia siliqua L.) in Morocco. Int. J. Pure App. Biosci. 2, 286-297.

El Baghati, H. (1995): La production des légumineuses alimentaires au Maroc. Al Awamia 89, 77-82.

El Hazzat, N., Artib, M., El Gabardi, S., Touati, J., Chliyeh, M., Ouazzani Touhami, A., Benkirane, R. and Douira, A. (2017): Study of the diversity of arbuscular mycorrhizal fungi in the highway slopes of Taza region (North-East of Morocco), Annual Research and Review in Biology 17, 1-10.

Farzaneh, M., Vierheilig, H., Lössl, A. and Kaul, H. P. (2011): Arbuscular mycorrhiza enhances nutrient uptake in chickpea. Plant Soil Environ. 57, 465-470.

Fortin, J. A., Plenchette, C. and Piché, Y. (2008): Les mycorhizes, La nouvelle révolution verte. Editions Multimondes, $135 \mathrm{p}$.

Gerdemann, J. W. and Nicolson, T. H. (1963): Spores for mycorrhizalendogone species extracted from soil by wet sieving and decanting. Trans. Br. Mycol. Soc. 46, 235-244.

Gianinazzi-Pearson, V., Dumas-Gaudot, E., Gollotte, A., Tahiri-Alaoui, A. and Gianinaizzi, S. (1996): Cellular and molecular defence-related root reponses to invasion by arbuscular mycorrhizal fungi. New Phytol. $113,45-57$.

Graham, P. H. and Vance, C. P. (2003): Legumes, importance and constraints to greater use - update on legume utilization. Plant Physiol. 131 p.

Haas, J. H. and Menge, J. A. (1990): VA-mycorrhizal fungi and soil characteristics in avocado (Persea americana Mill.) orchard soils. Plant and Soil 127, 207-212.

Hardy, R. W. H. and Hoolsten, R. D. (1985): Biological nitrogen fixation innaturel and agricultural habitats. In: M. H. Chafi (ed.): Etude préliminaire sur l'effet de quelques microéléments sur la fixation symbiotique d'azote. Diplôme des études supérieures de Biologie, Université d'Es Sénia, 62 p. 
Harrison, M. J. (1997): The arbuscular mycorrhizal symbiosis, an underground association. Trends in Plant Science 2, 54-60.

INVAM (2014): International culture collection of (vesicular) arbuscular mycorrhizal fungi. West Virginia University, Morgantown, West Virginia. Available:http://invam.wvu.edu/thefungi/species-descriptions.

Kachkouch, W., Ouazzani Touhami, A., Filali Maltouf, A., El Modafar, C., Moukhli, A., Oukabli, A., Benkirane, R. and Douira, A. (2012): Arbuscular mycorrhizal fungi species associated with rhizosphere of Olea europaea L. in Morocco. J. Animal and Plant Sciences 15, 2275-2287.

Kachkouch, W., Touati, J., Ouazzani Touhami, A., Filali-Maltouf, A., El Modafar, C., Moukhli, A., Oukabli, A., Benkirane, R. and Douira, A. (2014): Diversity of arbuscular mycorrhizal fungi in the rhizosphere of Olea europaea in three regions of Morocco (Tafilalt, Zagora and Taounate). Int. J. Pure App. Biosci. 2, $178-195$.

Karagiannidis, N. and Hadjisavva-Zinoviadi, S. (1998): The mycorrhizal fungus Glomus mosseae enhances growth, yield and chemical composition of a durum wheat variety in 10 different soils. Nut. Cycl. in Agroecosys 52, 1-7.

Khidir, H. H., Eudy, D. M., Porras-Alfaro, A., Herrera, J., Natvig, D. O. and Sinsabaugh, R. L. (2010): A general suite of fungal endophytes dominates the roots of two dominant grasses in a semiarid grassland. J. Arid. Environments 74, 35-42.

Lahlou, S., Ouadia, M., Malam Issa, O., Le Bissonnais, Y. and Mrabet, R. (2005): Modification de la porosité $\mathrm{du}$ sol sous les techniques culturales de conservation en zone semi-aride Marocaine. Etude et Gestion des Sols 12, 69-76.

Lambers, H., Raven, J. A., Shaver, G. R. and Smith, S. E. (2008): Plant nutrient-acquisition strategies change with soil age. Trends in ecology and evolution 23, 95-103.

Leal, P. L., Stürmer, S. L. and Siqueira, J. O. (2009): Occurrence and diversity of arbuscular mycorrhizal fungi in trap cultures from soils under different land use systems in the Amazon, Brazil. Brazilian J. Microbiol. $40,111-121$.

Mandyam, K. and Jumpponen, A. (2005): Abundance and possible functions of the root-colonising dark septale endophytic fungi. Stud. Mycol. 53, 173-189.

Mosse, B. (1973): Advances in the study of vesicular-arbuscular mycorrhiza. Ann. Rev. Phytopathol. 11, 171-196.

Mouelhi, B., Slim, S., Arfaoui, S., Boussalmi, A., Jarrahi, T. and Ben Jeddi, F. (2016): Impact de la rotation uulturale et du mode de semis sur les composantes physico-chimiques du sol et analyse de l'évolution des mycorhizes. Int. Multilingual J. Science and Technology 1, 70-81.

Mougel, C., Offre, P., Ranjard, L., Corberand, T., Gamalero, E., Robin, C. and Lemanceau, P. (2006): Dynamic of the genetic structure of bacterial and fungal communities at different development stages of Medicago truncatula Jemalong J5. New Phytologist 170, 165-175.

Nicolson, T. H. (1960): Mycorrhizae in the Gramineae II. Development in different habitats, particularly sand dunes. Trans. Brit. Mycol. Soc 43, 132-145.

Oehl, F., Sieverding, E., Ineichen, K., Mäder, P., Boller, T. and Wiemken, A. (2003): Impact of land use intensity on the species diversity of arbuscular mycorrhizal fungi in agroecosystems of Central Europe. Appl. Environ. Microbiol 69, 2816-2824.

Oehl, F., Sieverding, E., Palenzuela, J., Ineichen, K. and Alves da Silva, G. (2011): Advances in Glomeromycota taxonomy and classification. IMA Fungus 2, 1919.

Philips, J. M. and Hayman, D. S. (1970): Improved procedures for clearing roots and staining parasitic and vesicular arbuscular mycorrhizal fungi for rapid assessment of infection. Trans. Brit. Mycol. Soc. 55, $158-161$.

Sanaa, M. (1993): Dynamique et bilan de l'azote minéral dans quelques sols calcaires en Tunisie. Thèse de Doctorat. Université de Gent, Belgique $175 \mathrm{p}$.

Selmaoui, K., Artib, M., Semane, F., El Gabardi, S., Hibilik, N., El Aymani, I., Chliyeh, M., Mouria, A., Ouazzani Touhami, A., Benkirane, R. and Douira, A. (2017): Diversity of endomycorrhizal fungi (A.M.F.) in the rhizosphere of sugar cane (Saccharum officinarum) grown in Morocco. Int. J. Recent Scientific Research 8, 15753-15761.

Sghir, F., Chliyeh, M., Kachkouch, W., Khouader, M., Ouazzani Touhami, A., Benkirane, R. and Douira, A. (2013): Mycorrhizal status of Olea europaea spp. oleaster in Morocco. J. Appl. Biosciences 61, 44784489 . 
Sghir, F., Touati, J., Chliyeh, M., Ouazzani Touhami, A., Filali-Maltouf, A., Cherkaoui, E., Moukhli, A., Oukabli, A., Benkirane, R. and Douira, A. (2015): Diversity of arbuscular mycorrhizal fungi in the rhizosphere of date palm tree (Phoenix dactylifera) in Tafilalt and Zagora regions (Morocco). The American J. Science and Medical 1, 30-39.

Shi, Z, Y., Wang, F. and WeI, Y. L. (2007): Natural forest and forest plantation affect diversity of arbuscular mycorrhizal fungi in the Rhizosphere of Diptorocarpaceae. American-Eurasian J. Agric. Environ. Sci. 2, 411-416.

Smith, S. E. and Read, D. J. (2008): Mycorrhizal Symbiosis. 3rd ed. Academic Press, London, 750 p.

Soussi, M., Ocana, A. and Lluch, C. (1998): Effects of salt stress on growth, photosynthesis and nitrogen fixation in chickpea (Cicer arietinum L.). J. Exp. Bot. 49, 1329-1337.

St-Arnaud, M. and Vujanovic, V. (2007): Effect of the arbuscular mycorrhizal symbiosis on plant diseases and pests. In: C. Hamel and C. Plenchette (eds): Mycorrhizae in Crop Production. Haworth Food and Agricultural Products Press, Binghampton, NY, pp. 67-122.

Stutz, J. C., Coperman, R., Martin, C. A. and Morton, J. B. (2000): Patterns of species composition and distribution of arbuscular mycorrhizal fungi in arid region of southwestern north America and Namibia, Africa. Can. J. Bot. 78, 237-245.

Talbi, Z., Chliyeh, M., Selmaoui, K., Ouazzani Touhami, A., Benkirane, R. and Douira, A. (2014): Mycorrhizal status Juncus maritimus, riparian species of Sidi Boghaba Reserve (Northwest of Morocco). Int. J. Recent Scientific Research 5, 792-795.

Talbi, Z., El Asri, A., Touati, J., Chliyeh, M., Ait Aguil, F., Selmaoui, K., Sghir, F., Ouazzani Touhami, A., Benkirane, R. and Douira, A. (2015): Morphological characterization and diversity of endomycorrhizae in the rhizosphere of carob tree (Ceratonia siliqua) in Morocco. Biolife 3, 196-211.

Thomsen, M. H. and Haugaard-Nielsen, H. (2008): Sustainable bioethanol production combining biorefinery principals using combined raw materials from wheat undersown with clover-grass J. Ind. Microbiol Biotechnol. 35, 303-311.

Trouvelot, A., Kough, J. L. and Gianinazzi-Pearson,V. (1986): Mesure du taux de mycorhization VA d'un système radiculaire. Recherche de méthodes d'estimation ayant une signification fonctionnelle. In: V. Gianinazzi-Pearson and S. Gianinazzi (eds): Physiological and Genetical Aspects of Mycorrhizae. INRA Press, Paris, pp. 217-221.

Udvardi, M. and Poole, P. S. (2013): Transport and metabolism in Legume-Rhizobia symbioses. Annual Rev. Plant Biol. 64, 781-805.

Utobo, E. B., Ogbodo, E. N. and Nwogbaga, A. C. (2011): Techniques for extraction and quantification of arbuscular mycorrhizal fungi. Libyan Agriculture Research Center J. International 2, 68-78.

Valantin-Morison, M., Butier, A., Berder, J. and Pinochet, X. (2012): Crop growth and nitrogen utilization of a Mixture of Winter oilseed rape (Brassica napus-WOSR) and legume in multi-local trials. Proc. of the XIIth Congress of the European Society of Agronomy, Helsinki, pp. 19-24.

Walker, C. (1992): Systematic and taxonomy of the arbuscular mycorrhizal fungi. Agronomie 12, 887-897.

Wery, J. and Grignac, P. (1983): Les utilisations des légumineuses et leurs importances économiques. II syst. 4 in fiche technique de la fixation symbiotique de l'azote FAO. 